\title{
Preserving large farming landscapes: The case of Lancaster County, Pennsylvania
}

\author{
Tom Daniels ${ }^{a} *$ and Lauren Payne-Riley ${ }^{\mathrm{b}}$ \\ University of Pennsylvania
}

Submitted December 2, 2016 / Revised February 10, and April 20, 2017 / Accepted May 7, 2017 /

Published online May 30, 2017

Citation: Daniels, T., \& Payne-Riley, L. (2017). Preserving large farming landscapes: The case of Lancaster

County, Pennsylvania. Journal of Agriculture, Food Systems, and Community Development, 7(3), 67-81.

http://dx.doi.org/10.5304/jafscd.2017.073.004

Copyright (C) 2017 by New Leaf Associates, Inc.

\begin{abstract}
Preserving large farming landscapes is one of the main goals of farmland preservation programs. Other goals include protecting highly productive soils, maintaining and enhancing the local farming economy, and promoting locally produced fresh food. Farmland preservation programs take time, however, because of the hefty funding requirements and the detailed process of preserving farmland through the acquisition of conservation easements by purchase or donation. The standard measures of dollars spent and farmland acres preserved do not give an accurate picture of the spatial outcomes of preservation and preservation
\end{abstract}

a Tom Daniels, Professor, Department of City and Regional Planning; 127 Meyerson Hall; School of Design; University of Pennsylvania; 210 South 34th Street; Philadelphia, PA 191046311 USA.

b Lauren Payne-Riley, Master's Candidate, Department of City and Regional Planning; 127 Meyerson Hall; School of Design; University of Pennsylvania; 210 South 34th Street; Philadelphia, PA 19104-6311 USA; lpayn@design.upenn.edu

* Corresponding author: Prof. Tom Daniels, 590 Northlawn

Drive; Lancaster, PA 17603 USA; +1-717-368-0559;

thomasld@design.upenn.edu effectiveness. Three other measures better reflect the spatial effectiveness of farmland preservation: acreage and percentage of preserved farm parcels located in agricultural zones, number and acreage of preserved farm parcels in large contiguous blocks, and number and acreage of preserved farm parcels along growth boundaries. Scattered preserved farms and preserved farms not located in agricultural zones are likely to face more nonfarm development nearby as well as problems with nonfarm neighbors. The farmland preservation effort in Lancaster County, Pennsylvania, provides an important case study of the pattern of farmland preservation over time. Other counties and land trusts can employ geographic information systems (GIS) methods in this study to monitor and evaluate the progress of their farmland preservation efforts.

\section{Keywords}

Farmland Preservation; Geographic Information Systems (GIS); Agricultural Zoning; Urban Growth Boundaries

\section{Disclosure}

Tom Daniels was the director of the Lancaster County Agricultural Preserve Board from 1989 to 1998. 


\section{Introduction}

Federal, state, and local government programs for farmland preservation, as well as preservation efforts from private, nonprofit land trusts, are wellestablished (Daniels \& Bowers, 1997; Liu \& Lynch, 2011; Sokolow, 2006a, 2006b; Sokolow \& Zurbrugg, 2003; Sorenson, Greene, \& Russ, 1997; Stoms, Jantz, Davis, \& DeAngelo, 2009). Nevertheless, between 1982 and 2012 more than 42 million acres ${ }^{1}$ of land-including at least 24 million acres of agricultural land-were converted to development (U.S. Department of Agriculture [USDA], 2015). Although the conversion of farmland has not threatened the nation's food supply, it has posed challenges to farming industries in several metropolitan areas, such as declining farm-support businesses as fewer farms remain, increasing conflicts between farmers and nonfarm neighbors, and rising land prices, which make entry into farming and the expansion of farms difficult (Heimlich \& Anderson, 2001; Sorenson et al., 1997).

Since 1996, the federal government has provided more than US $\$ 1$ billion in matching grants to state and local governments and land trusts for the purchase of conservation easements to farmland through the Farm and Ranchland Protection Program and its successor, the Agricultural Conservation Easement Program managed by the Natural Resources Conservation Service (NRCS) (American Farmland Trust, 2013; NRCS, 2017). A conservation easement is a legally binding document that restricts the use of a property to farming and open space, usually in perpetuity. A landowner may voluntarily sell or donate a conservation easement to a government agency or private land trust and a deed of easement is recorded at the county courthouse. The land remains in private ownership, and may be sold or passed on to heirs, but the restrictions apply to all future landowners (Daniels, 1991). As of 2015, 28 states had passed legislation creating programs to purchase conservation easements and had spent nearly US $\$ 4$ billion to preserve more than 2.5 million acres (American Farmland Trust, 2015). As of 2012, nearly 100 counties and other local governments had created and

${ }^{1}$ Note: 1 acre $=0.4$ hectare funded farmland preservation programs (American Farmland Trust, 2012); more than 500 land trusts listed farmland preservation as one of their top priorities in a 2011 national survey, and these land trusts reported that they had preserved more than 3 million acres of agricultural land (Land Trust Alliance, 2011; American Farmland Trust, 2013).

Since the first agricultural conservation easement was purchased in 1974 in Suffolk County, New York, government agencies and private land trusts across America have spent more than US $\$ 5$ billion purchasing conservation easements to farmland and have preserved more than 5 million acres (American Farmland Trust 2016a, 2016b; Daniels \& Wright, 2015; Liu \& Lynch, 2011; NRCS, 2016). While this preserved land is a small portion of the nation's 900 million acres of farm and ranchland, at least half of the roughly 3 million acres of preserved farm land-not including ranch land-has been preserved in about 50 metropolitan counties (Daniels \& Wright, 2015; Sokolow \& Zurbrugg, 2003). Metropolitan areas are generally under significant development pressure, yet they often contain high-quality agricultural land and have the potential to provide fresh produce to nearby cities and suburbs.

The preservation of farmland has four main goals: (1) protecting highly productive agricultural soils on a long-term basis; (2) maintaining and enhancing local and regional agriculture; (3) providing opportunities to produce fresh local food for local consumers; and (4) preserving large farming landscapes (Stoms et al., 2009). These goals often overlap with goals to slow the rate of farmland loss, limit the fragmentation of farmland, keep farmland affordable for new and expanding farm operators, and provide nearby open space for urban dwellers (Liu \& Lynch, 2011; Lynch \& Liu, 2007; Stoms et al., 2009).

The potential benefits of preserving large farming landscapes include (1) maintaining a critical mass of farms and farmland to enable farmsupport businesses to continue; (2) keeping development at a distance from farms, so that development pressures and conflicts with nonfarm neighbors are kept to a minimum; (3) channeling growth to areas with adequate infrastructure; and (4) creating a local farm-business climate that promotes 
succession to the next generation (Schilling, Esseks, Duke, Gottlieb, \& Lynch, 2015).

Acquiring conservation easements on large farming landscapes requires planning, funding, and willing landowners (Daniels \& Bowers, 1997; Gerber \& Rissman, 2012; Sokolow, 2006a). Some of the nation's leading counties in farmland preservation, such as Baltimore County, Maryland, and Sonoma County, California, use three interrelated techniques: (1) restrictive agricultural zoning; (2) urban growth boundaries; and (3) the purchase of conservation easements on farmland (Daniels, 2010; Sokolow, 2006b). First, a local government can recognize the importance of agriculture in its comprehensive plan and adopt goals to protect and preserve farmland. To help implement the comprehensive plan, agricultural zoning can limit the number of nonfarm dwellings allowed, such as only one house per 40 acres. Urban growth boundaries are typically agreed upon between cities and a neighboring county to restrict the extension of sewer and water lines and thus urban development from the countryside. .

By reducing the potential for nonfarm development, urban growth boundaries and agricultural zoning tend to make land more affordable for farming, so the farmland preservation option is more attractive. Both urban growth boundaries and agricultural zoning are important tools for protecting farmland over the short- to medium-term. Neither of these tools actually preserves farmland, however, and both can be changed by elected governing bodies (Bengston, Fletcher, \& Nelson, 2004).

Farmland preservation over the long term usually involves the sale of a conservation easement, also known as development rights, to a government agency or land trust. Farmland preservation is a legal process in which a landowner voluntarily signs a deed of easement to restrict the development of the land to agricultural and open space uses, usually in perpetuity (Daniels, 1991). Once the deed of easement is recorded in the land records at the county courthouse, the restrictions in the deed of easement "run with the land," thus applying to all future landowners. The landowner receives a payment for the conservation easement from the land trust or government agency, based on an appraisal of the value of the conservation easement. A landowner may donate a portion of the easement value in a "bargain sale" involving part cash and part donation (Daniels \& Bowers, 1997). The landowner can use the value of the donation as a tax deduction. Clearly, the higher the landowner's income, the more valuable the deduction in tax savings. Land trusts often have relatively little cash on hand to purchase conservation easements, and so they often preserve land through a bargain sale of a conservation easement, involving part cash paid to the landowner and part donation by the landowner. A landowner may even donate the full easement value.

Success of farmland preservation programs is generally judged according to dollars spent and acres preserved (Lynch \& Musser, 2001). But if a major goal is to preserve large agricultural landscapes, a farmland preservation program must prioritize land for conservation easement acquisition (Sokolow \& Zurbrugg, 2003; Tulloch, Myers, Hasse, Parks, \& Lathrop, 2003). To assess the effectiveness of a prioritization strategy, it is important to determine whether farmland is being preserved in contiguous blocks rather than in scattered parcels, and in locations consistent with public policies, such as comprehensive plans and agricultural zoning, and to manage the location and pattern of growth by limiting or directing urban expansions, such as preservation consistent with an urban growth boundary (Lynch \& Liu, 2007; Machado, Stoms, Davis, \& Kreitler, 2006; Sokolow, 2006b; Stoms et al., 2009).

Most state and local governments that are active in purchasing conservation easements do not have agricultural zones, and very few have growth boundaries or urban service boundaries. In these states and municipalities, it is still important to determine whether government programs and land trusts are preserving farmland in contiguous blocks or in a scattered pattern. Without restrictive agricultural zoning, a scattered pattern of land preservation can act like magnets for nonfarm residential development. Data have shown that the value of nonpreserved land rises when it is next to preserved land (Daniels \& Bowers, 1997). But nonfarm residents often complain about the noise, dust, and odors of neighboring farming operations. 
In addition, without limits on sewer and water extensions, these services can penetrate farther into the countryside, inducing the conversion of farmland to intense development. But a farmland preservation program may not actually be able to preserve farmland along urban growth boundaries to make the boundaries more difficult to expand into farming areas. Stoms et al. (2009) pointed out this shortcoming in their study of acquisition of agricultural conservation easements in the San Francisco Bay Area.

The focus of this paper is whether and to what extent geographic information systems (GIS) can help to evaluate the implementation of a strategy to preserve large farming landscapes, as well as help to guide the strategy. To test these roles for GIS, we used GIS to analyze the location of preserved farms in Lancaster County, Pennsylvania, according to four criteria: (1) whether the farm is located in an agricultural zoning district, consistent with public policy (Stoms et al., 2009); (2) the number and size of contiguous blocks of preserved farmland (Brabec \& Smith, 2002); (3) the number of acres of preserved farmland adjacent to an urban growth boundary (Machado et al., 2006); and (4) the location of easement sale applications relative to existing preserved farms (Daniels \& Bowers, 1997).

\section{Farmland Preservation in Lancaster County, Pennsylvania}

Lancaster County, Pennsylvania, has one of the nation's leading farmland preservation programs. Since 1983, the county Agricultural Preserve Board, with the Lancaster Farmland Trust and the Brandywine Conservancy (based in neighboring Chester County), have preserved more than 100,000 acres, placing Lancaster County first among counties nationwide in the amount of preserved farmland (Daniels \& Wright, 2015). The mission statement of the Agricultural Preserve Board is "to forever preserve the beautiful farmland and productive soils of Lancaster County and its rich agricultural heritage; and to create a healthy environment for the long-term sustainability of the agricultural economy and farming as a way of life" (Lancaster County Government Center, n.d.-a, para. 1). But the Preserve Board's conservation easement program guidelines do not mention preserving a farm based on its appearance, but rather on its soil quality, farm viability, development pressure, and proximity to already preserved farms (Lancaster County Agricultural Preserve Board, 2010). This last factor represents the goal of preserving farmland in large blocks.

Lancaster County also has long had robust geographic information systems (GIS) data that provides an opportunity to measure progress over time toward landscape-scale farmland preservation. Thus far, GIS has been used largely to identify parcels for preservation and to keep track of preserved properties (Hoobler, Vance, Hamerlinck, Munn, \& Hayward, 2003; Tulloch et al., 2003). Yet GIS offers a compelling method to analyze the spatial performance of a farmland preservation program and to provide insights about both accomplishments and adjustments that would enable a farmland preservation program to better achieve its landscape-scale preservation goal (Stoms et al., 2009).

Lancaster County covers 603,000 acres in southeastern Pennsylvania, approximately 60 miles (97 kilometers) west of Philadelphia. The county contains some of the most productive farmland in the nation; about two-thirds of the county is in farm use (USDA, 2014). The average farm size is only 85 acres, in part because of the presence of Plain Sect farmers (Amish and Mennonite), who farm with animals rather than machinery (Daniels, 2000). Agriculture is a US $\$ 1.5$ billion a year industry in Lancaster County, with large dairy, egg, and poultry production (USDA, 2014). Yet the county population in 2012 was 519,445 people, which defines the county as a metropolitan area. Moreover, in the 1990s and 2000s, Lancaster County's population grew by 11 percent, well above the statewide rate of only 3.4 percent (U. S. Bureau of the Census, 2011), so the county has faced significant development pressures that show little sign of abating.

In the late 1970s Lancaster County began to experience development pressure from the sprawling Philadelphia metropolitan area, as well as from internal growth. In 1980 the Lancaster County commissioners appointed a nine-member Agricultural Preserve Board to develop strategies to pro- 
tect farmland. The board called for the creation of a purchase of agricultural conservation easements program to preserve farmland. The county program began in 1983. In 1976, townships ${ }^{2}$ in Lancaster County began to adopt agricultural zoning ordinances, which limited nonfarm development in the countryside. More than half of Lancaster County, about 325,000 acres, is now zoned for agriculture (Lancaster County Planning Commission, 2010, p. 7), and effective agricultural zoning is found in 38 of the county's 41 townships. Effective agricultural zoning means that only one new house is allowed per 20 acres, and the house must be on a lot of no more than 2 acres (Lancaster County Planning Commission, 2010, p. 3). While effective agricultural zoning is a strong land use policy, the zoning can be changed by the elected township officials at any time, if they so desire. The fact that zoning can be changed can hinder farmland preservation efforts by adding uncertainty for farmers deciding whether to preserve their farms and for public officials and private donors deciding whether to fund farmland preservation programs.

By the late 1980s, the county planning commission was pushing the townships, villages, and urban core to create urban and village growth boundaries to promote more compact growth by limiting the extension of sewer and water lines. The first urban growth boundary in Lancaster County was formed in 1993. Since then 13 urban growth boundaries and village growth boundaries have been put in place around cities and villages through voluntary agreements (Lancaster County Planning Commission, 2006). Today, nearly 112,000 acres, more than one-sixth of the total acreage of the county, lies within an urban or village growth boundary. Within these boundaries, enough "buildable" land exists to accommodate development over a 20 -year period, based on population growth projections and expected land use needs.

Every three to five years, the county may review and recommend changes to the boundaries.

\footnotetext{
${ }^{2}$ A township covers about 20,000 to 30,000 acres, and a township government has control over planning and zoning within its boundaries.
}

But if land adjacent to an urban or village growth boundary is protected from development through the sale or donation of a conservation easement, the boundary cannot be extended at that location. Thus, preserved farmland along a boundary "locks in" that part of the boundary, and forces future boundary expansions to occur somewhere else.

Since 1983 the Agricultural Preserve Board has administered the county purchase of agricultural conservation easements program, and has received funding from the county government, the state of Pennsylvania, the federal Farm and Ranchland Protection Program, and the new Agricultural Conservation Easement Program, created through the 2014 farm bill. Landowners may apply to sell a conservation easement to the Preserve Board, which then "ranks the applications for priority, hires appraisers to estimate the value of development rights, and makes a formal offer to the landowner" (Lancaster County Government Center, n.d., "History of the Board," para. 1).

In 1988, the nonprofit Lancaster Farmland Trust was created to add a private farmland preservation effort especially for preserving farmland owned by the Amish, who generally do not want to receive government funds. In addition, in 1998 the private nonprofit Brandywine Conservancy, based in neighboring Chester County, acquired donated conservation easements on farms in southeastern Lancaster County.

Since 1989, the Agricultural Preserve Board has enjoyed an average budget of more than US $\$ 5$ million a year to acquire conservation easements, or about US $\$ 175$ million in total. The Farmland Trust has had a policy of stretching its dollars by offering less than US $\$ 1,500$ an acre for conservation easements; many of its acquisitions are either donations of conservation easements or bargain sales involving part cash and part donation of easement value. The Preserve Board and the Farmland Trust have had a cooperative agreement since 1989 and have combined efforts to preserve a dozen farms.

\section{Assessing the Progress of Lancaster County's Farmland Preservation Effort}

The purpose of this study is to assess the progress of Lancaster County toward its goal of preserving a 
large-scale farming landscape according to three criteria:

(1) Consistency of farmland preservation with agricultural zoning; that is, farmland zoned for agriculture should be preserved, not land that iszoned for rural residential development or commercial or industrial development (Stoms et al., 2009). The greater the number of farm parcels and acreage within effective agricultural zoning districts, the less likelihood of conflicts with nonfarm neighbors and the greater the likelihood of being able to create large blocks of preserved farmland at a landscape scale.

(2) Changes in the patterns of land preservation between 2007 and 2016; specifically, the number and size of contiguous blocks of preserved farm parcels, which show the degree to which farmland is being preserved in large blocks or in a scattered pattern. The size of the contiguous blocks should grow over time if the acquisition of conservation easements is strategic; otherwise, if the blocks do not expand, this suggests a more opportunistic and scattered approach to easement acquisition, which will not provide as much protection for preserved farms (Stoms et al., 2009).

(3) Preservation of farmland along growth boundaries to limit or direct future expansions of the boundaries. The more farmland is preserved along growth boundaries, it is less likely the boundaries will move outward over time and the more likely that there will be a separation between urban and rural land (Machado et al., 2006).

The results point out strengths and weaknesses of the county farmland preservation efforts and suggest potential worthwhile changes in preservation strategy.

\section{Methodology}

The analysis consists of four parts. First, we identified the total number of preserved farm parcels and preserved farmland acres in Lancaster County (Table 1). Next, we determined the number of preserved farm parcels and acreage in effective agricultural zones for 2007 and 2016 (Table 1). Then, we computed the number and acreage of the contiguous preserved farm parcels in the county for both 2007 and 2016 (Tables 2 and 3). Last, for 2007 and 2016 we determined the number of miles of urban and village growth boundaries and the number of miles of preserved farmland along the growth boundaries.

The Lancaster County GIS Department provided data on preserved farms, agricultural zoning, and growth boundaries. The data contained information on the location of land zoned for effective agriculture, urban growth boundaries, and the individual preserved farm parcels. It is important to note that the number of preserved farm parcels $(2,259$ in 2016) does not reflect the actual number of preserved farms in the county, which is slightly more than 1,300. The term "farm parcel" refers to the fact that a farm, although under one owner, is displayed in the GIS dataset as having more than one parcel of land if the farm is divided by roads, waterways, or power lines.

We used ESRI ArcMap geographic information systems software and tools available in the Arc Toolbox to analyze data for each parcel
Table 1. Total Preserved Farm Parcels and Acreage, 2007 and 2016, and Preserved Farm Parcels in Agricultural Zones, 2007 and 2016

\begin{tabular}{lcc}
\hline Years & Total Preserved Farm Parcels & Preserved Acreage \\
\hline 2007 & 1,543 & 71,910 \\
\hline 2016 & 2,259 & 102,678 \\
\hline & $\begin{array}{c}\text { Preserved Farm Parcels in } \\
\text { Agricultural Zones }\end{array}$ & Preserved Acreage \\
\hline 2007 & 1,479 & 69,287 \\
\hline 2016 & 2,194 & 100,094 \\
\hline
\end{tabular}

Note: 1 acre $=0.40$ hectare 
and for the county as a whole. We first identified the total number of preserved farm parcels and preserved acres for 2007 and 2016. Then, we used "select by location" by centroid of the GIS polygons in the GIS software. This method enabled us to select both the preserved farms GIS layer and the agricultural zoning layer to determine how many farm parcels fell within effective agricultural zoning districts.

We next measured the contiguity of the preserved farm parcels by reconfiguring the farm parcels into contiguous blocks. A contiguous block was defined as any number of groups of farm parcels that share a common property line or are separated only by a roadway. To accomplish this

Table 2. Contiguous and Stand Alone Farms by Acreage, 2007

\begin{tabular}{lcc}
\hline \multicolumn{1}{c}{ Farm Blocks in Acres } & Number of Blocks & Acreage in Block \\
\hline TOTAL & 339 & 71,910 \\
Contiguous Blocks & 231 & 65,743 \\
1000 or more & 9 & 20,927 \\
$500-999$ & 18 & 12,112 \\
$250-499$ & 37 & 13,039 \\
250 or Less & 167 & 25,832 \\
Stand-alone Parcels & 108 & 6,167 \\
Within 1/2 Mile of a Contiguous Block & 76 & 4,382 \\
Beyond 1/2 Mile of a Contiguous Block & 32 & 1,785 \\
\hline
\end{tabular}

Note: 1 acre $=0.4$ hectare

Table 3. Contiguous and Stand Alone Farms by Acreage, 2016

\begin{tabular}{lcc}
\hline \multicolumn{1}{c}{ Farm Blocks in Acres } & Number of Blocks & Acreage in Block \\
\hline TOTAL & 358 & 102,678 \\
\hline Contiguous Blocks & 244 & 96,325 \\
\hline 1000 or more & 17 & 47,809 \\
\hline $500-999$ & 22 & 14,594 \\
\hline $250-499$ & 41 & 14,810 \\
\hline Less than 250 & 164 & 19,508 \\
\hline Stand-alone Parcels & 114 & 6,353 \\
\hline Within $1 / 2$ Mile of a Contiguous Block & 80 & 4,880 \\
\hline Beyond $1 / 2$ Mile of a Contiguous Block & 34 & 1,473 \\
\hline
\end{tabular}

Note: 1 acre $=0.4$ hectare reconfiguration, the boundaries between farms that were touching were dissolved to create polygons that included multiple farms. Then a buffer was placed around the farms at one half the width of the road right-of-way, to account for farms that were separated by a road. The contiguous farm parcels were joined together and then clipped back to their original shapes based on the outline of the original shapefile.

Last, we measured the length of the urban and village growth boundaries. We obtained the total outside perimeter of the growth boundaries by dissolving the growth boundary polygons based on type and then removing interior lines. We then calculated the perimeter of the resulting polygons, and determined how many miles of preserved farmland and how many farm parcels shared an edge with a growth boundary. To perform this task we employed a "select by location" with a small buffer to account for roads. Farm parcels that were adjacent to a growth boundary but fell just outside the buffer were selected by hand.

\section{Results and Discussion}

Total Farmland Acres Preserved For 2007, we identified a total of 1,543 preserved farm parcels and 71,910 preserved acres. For 2016, there were 2,259 preserved farm parcels and 102,678 preserved acres, an increase of 30,768 acres and 43 percent more preserved acres in nine years (Table 1). This is a strongly positive trend for a county-level farmland preservation program.

\section{Farmland Acres Preserved in Agricultural Zones}

For 2007, we found 1,479 preserved farm parcels in 
effective agricultural zones. These parcels composed 95 percent of the preserved farm parcels and accounted for almost 70,000 acres or 96 percent of the preserved farmland (Table 1 and Figure 1). For 2016, there were 2,194 preserved farm parcels located in effective agricultural zones, making up over 97 percent of all preserved farm parcels (Table 1 and Figure 2). The number of preserved farmland acres in effective agricultural zones also grew to 100,094 , an increase of 30,807 acres or 44 percent from 2007.

In 2007, there were 64 preserved farm parcels (4.1 percent of all preserved parcels) located outside of an effective agricultural zone and covering 2,623 acres (3.6 percent of all preserved farmland). In 2016, 65 preserved farm parcels (2.9 percent of all preserved parcels) covering 2,584 acres (2.5 percent of all preserved farmland) were located outside of an effective agricultural zone.

The Agricultural

Preserve Board has long favored the preservation of farmland in agricultural zones, and in 2000 the board adopted a policy to preserve farms only in agricultural zones. The Lancaster Farmland Trust does not have such a policy, and has continued to preserve some farms that are not in agricultural zones.

In sum, the overwhelming majority of farms that are preserved in Lancaster County are in effective agricultural zones, which is consistent with public policy and planning. The proportion of preserved farm parcels and acres in agricultural zones has increased between 2007 and 2016. This is a positive trend, because effective agricultural zoning reduces the likelihood of intensive nonfarm devel- opment on neighboring properties that could result in complaints and conflicts over farming operations.

\section{Contiguity of Preserved Farmland}

In 2007, preserved farm parcels in blocks of two or more totaled to 231 contiguous blocks of farmland, 1,435 parcels (93 percent of all preserved parcels), and 65,743 acres (91 percent of all preserved farmland). There were 108 stand-alone farm parcels in 2007 (Table 2 and Figure 1). The average size of a block of preserved farmland was 285 acres. The largest contiguous block contained 201 farm parcels and covered 8,676 acres. In addition, there were nine contiguous blocks totaling 1,000 or more acres and 18 contiguous blocks totaling between 500 and 999 acres. Of concern, however, was the fact that the predominant contiguous block Figure 1. Preserved Farm Parcels, Urban Growth Areas, and Effective
Agricultural Zoning, Lancaster County, Pennsylvania, 2007

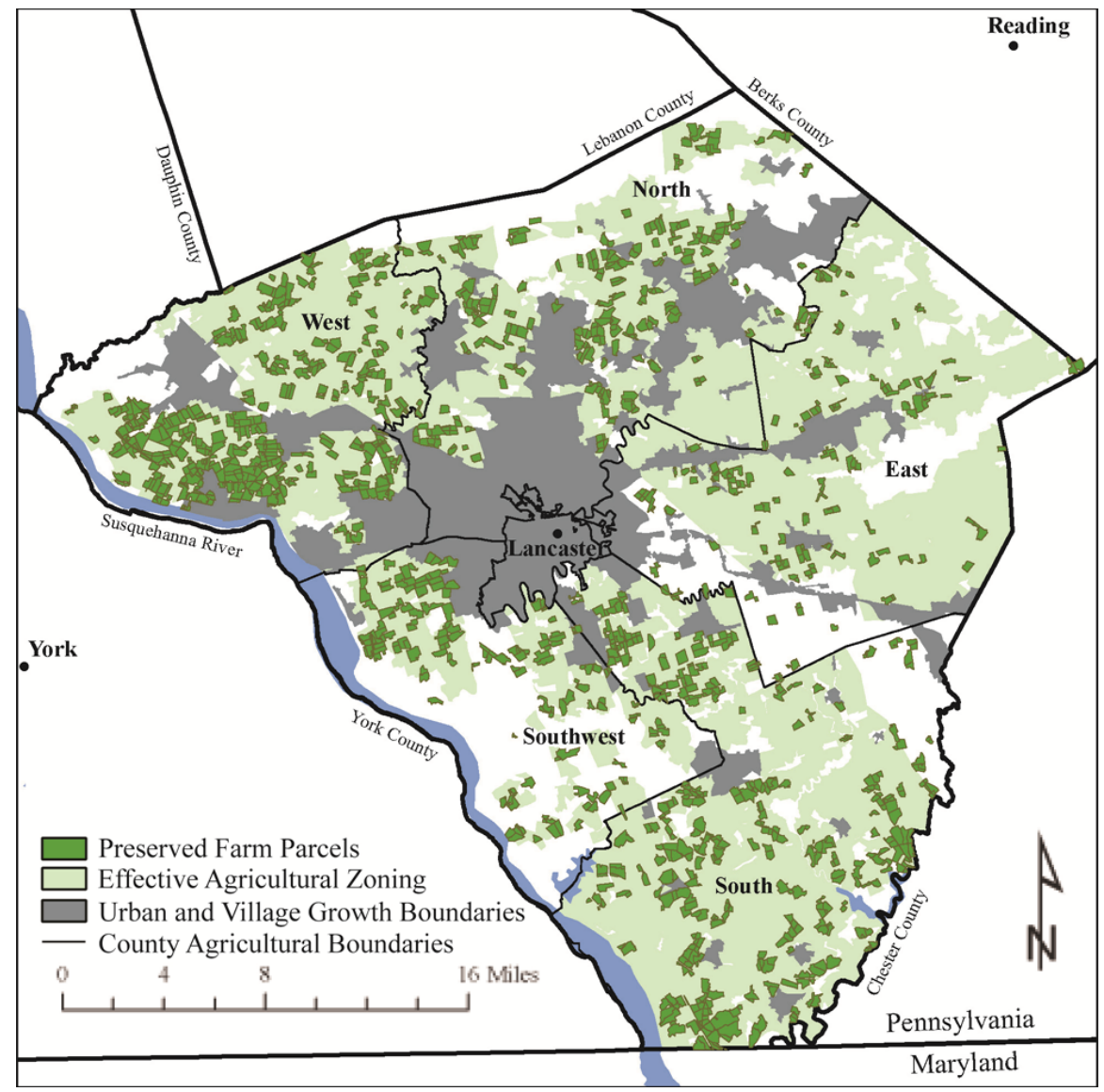

Figure courtesy of Christina Arlt; used by permission. 
size was less than 250 acres, with 167 contiguous blocks accounting for more than 25,000 acres, or greater than one-third of the preserved farmland in the county. The average size of a block of less than 250 acres was 155 acres. These relatively small blocks of preserved farmland could be somewhat vulnerable to adjacent nonfarm developments and complaints over farming practices. This result suggests that the county farmland preservation efforts need to produce larger contiguous blocks of preserved farmland. Large blocks of preserved farmland of 500 or 1,000 or more acres have more "interior" preserved farmland, and thus are generally less vulnerable to potential conflicts with nearby nonfarm development than blocks of less than 250 acres.

In 2016, there were 244 preserved farm parcels (93.2\% of preserved parcels) in blocks of two or more parcels, and 96,325 acres $(93.8 \%$ of preserved farmland) in those blocks. The amount of

\section{Figure 2. Preserved Farm Parcels, Urban Growth Areas, Effective Agricultural Zoning, and Preserved Farm Boundaries Touching Growth Boundaries, Lancaster County, Pennsylvania, 2016}

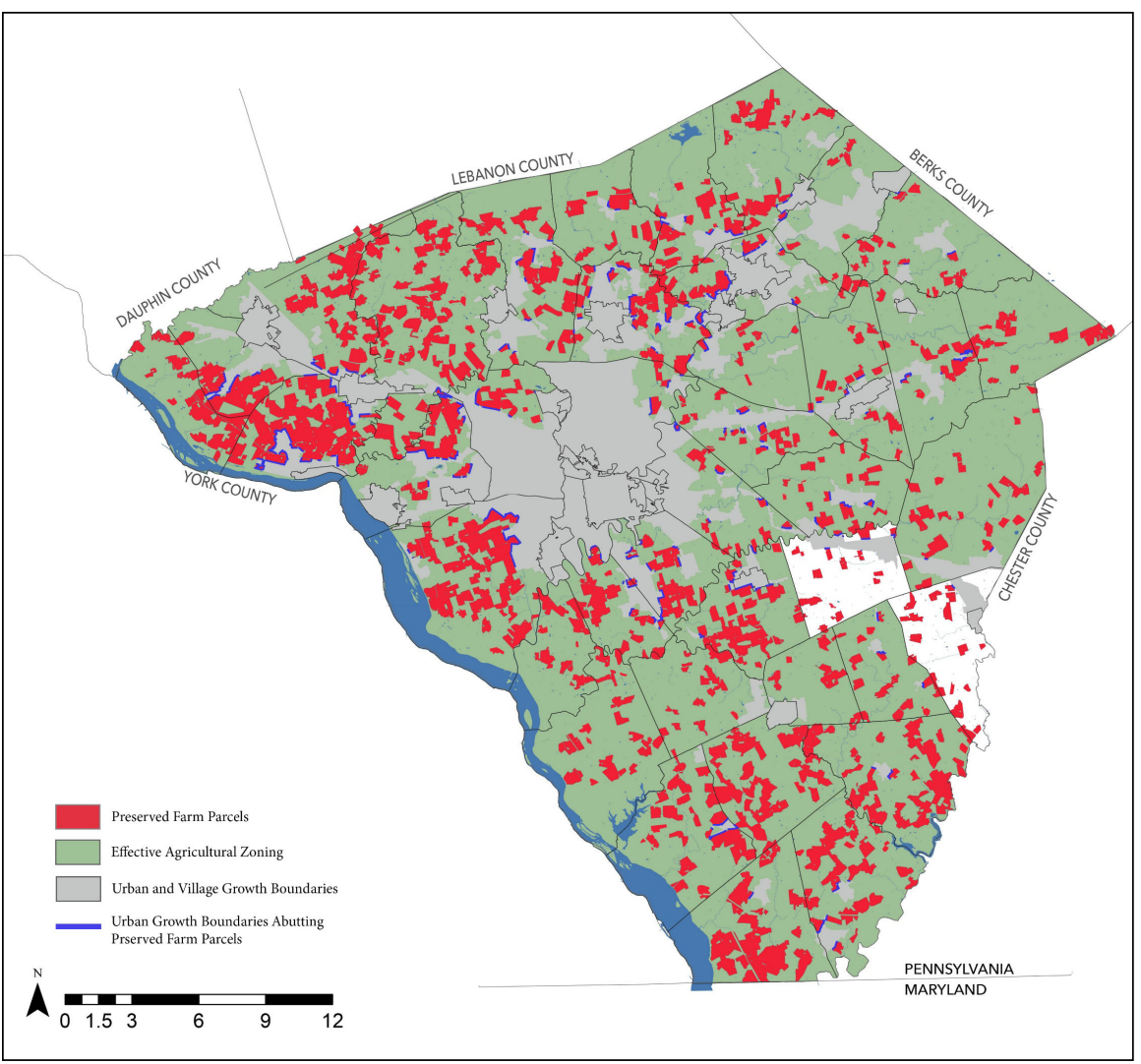

preserved farmland in contiguous blocks grew by 30,582 acres between 2007 and 2016. There were 108 stand-alone preserved farm parcels in 2007, covering 6,167 acres. By 2016, the number of stand-alone farm parcels had increased slightly to 114 and their acreage edged up to 6,353 acres (Table 3 and Figures 1 and 2). The average size of a block of preserved farmland increased from 285 acres in 2007 to 395 acres in 2016. These overall results strongly suggest that the pattern of preserved farms has grown less dispersed over time, in keeping with the contiguity strategy.

Another indication of this greater contiguity is that the largest contiguous block in 2007 contained 201 preserved farm parcels and covered 8,676 acres, and in 2016 that block grew to 261 parcels and covered 10,733 acres.

The most notable change among the contiguous blocks between 2007 and 2016 was the increase in the number and acreage of blocks of more than 1,000 acres. The number of blocks nearly doubled to 17 and the preserved acreage in those blocks more than doubled from 20,927 acres to 47,809 acres, or from 29 percent of the county total preserved farmland to 47 percent.

There were 22 blocks between 500 and 999 acres, covering 14,594 acres. The number of blocks between 250 and 499 acres grew to 41 and covered 14,810 acres. The number of blocks of less than 250 acres held rather steady at 164 blocks, but the acreage in these blocks declined by more than 6,700 acres, or 22 percent, to 19,113 acres. This suggests that at least some of the blocks of less than 250 acres were added to larger nearby blocks or simply grew into larger blocks of preserved 
farmland. Even so, these results imply that the Preserve Board and the Lancaster Farmland Trust need to continue efforts to preserve farmland adjacent to existing blocks of less than 250 acres to expand those blocks with a goal of at least 500 acres per block. A 500 -acre block would be much more difficult to surround with nonfarm development and would create more interior preserved farmland. The small blocks of preserved farmland, even if they are in areas zoned for agriculture, may be vulnerable to nonfarm development next door because they provide a "preserved view."

Of the 108 stand-alone farms in 2007, 76 were located within one half-mile of an existing contiguous block, while 32 were beyond one halfmile. The stand-alone farms accounted for 6,167 acres or just under nine percent of the total preserved farmland in the county. The 114 standalone farms in 2016 consisted of 6,353 acres, or about 6 percent of the county preserved farmland. Eighty of the stand-alone parcels were within one half-mile of another preserved farm, and 34 were beyond one half-mile.

Again, the results point to a trend toward greater overall contiguity of preserved farms.

The Agricultural Preserve Board gives higher weighting in its application ranking system for farms adjacent to a preserved farm or within one half-mile of a preserved farm. This strategy appears to be working. The Lancaster Farmland Trust has traditionally pursued a more opportunistic approach to preservation, with less emphasis on contiguity or proximity to another preserved farm. However, the Trust has recently begun to emphasize the creation and expansion of blocks of preserved farmland (Lancaster Farmland Trust, 2016).

\section{Preserved Farmland and Urban Growth Boundaries}

We found that in 2007 Lancaster County had a total of 583 miles of urban growth boundaries. We determined that 65 miles of preserved farmland shared a common edge with an urban growth boundary. In other words, there are preserved farm parcels along 11.1 percent of the growth boundaries.

In 2007, 209 preserved farm parcels shared a common edge with a growth boundary. The Agricultural Preserve Board had, until 2000, pursued a strategy of preserving farms along growth boundaries because these farms were under the most development pressure and, if preserved, could obstruct development from penetrating into high-quality farming areas. The Preserve Board
Figure 3. Preserved Farms, Agricultural Easement Sale Applications, Effective Agricultural Zoning, and Urban Growth Areas in Lancaster County, Pennsylvania, 2016

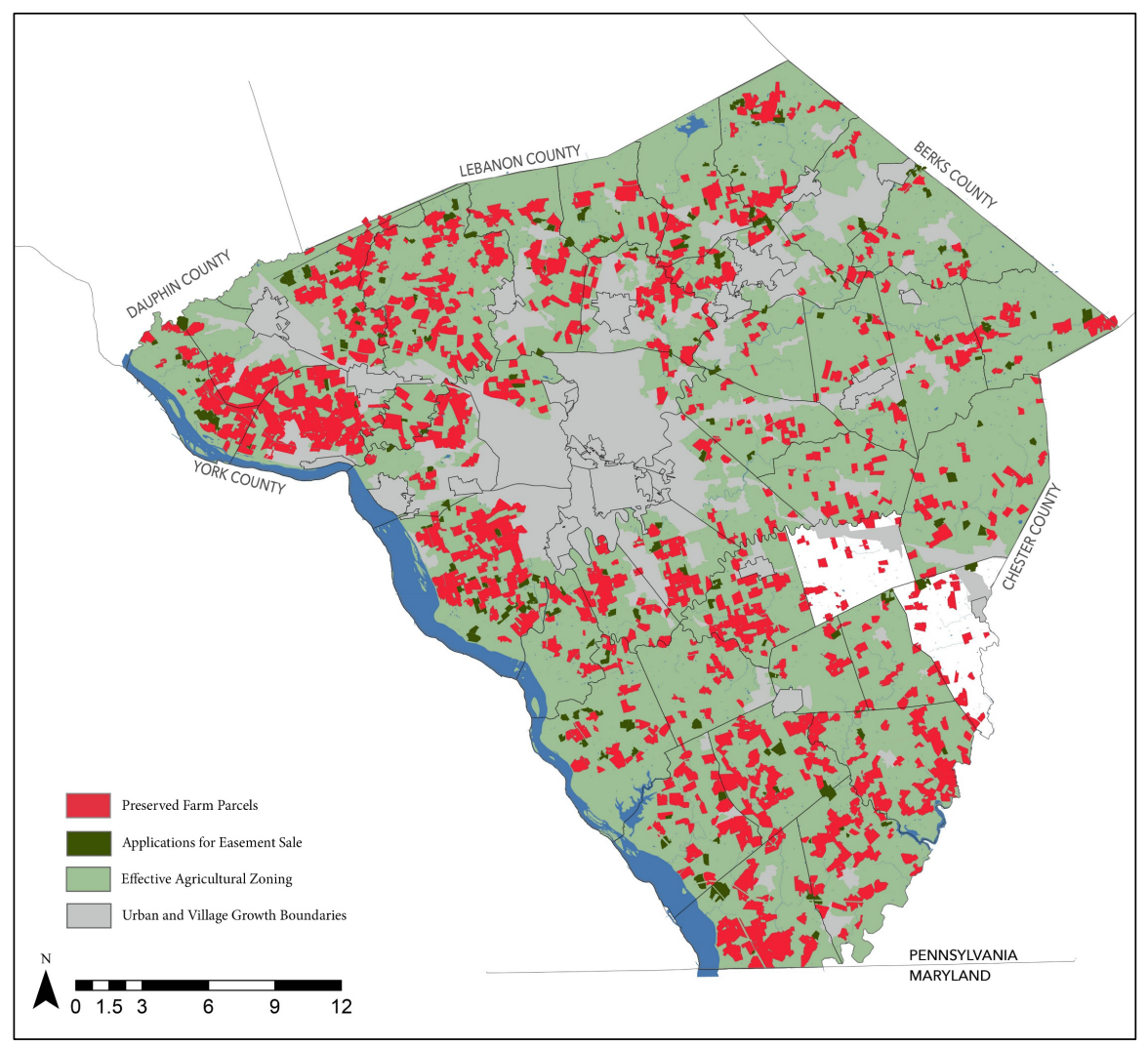


average cost per acre to purchase development rights (slightly more than US $\$ 3,000$ ) reflects an attempt to preserve those farms under moderate to significant development pressure close to built-up areas. In 2000, the county adopted a policy of paying no more than US $\$ 4,000$ an acre for a conservation easement in order to reduce the likelihood of preserving farmland along growth boundaries, where some farms had been preserved at a cost of more than US $\$ 5,000$ an acre. The Farmland Trust does not have the financial resources to purchase conservation easements along growth boundaries, and generally targets farms away from them.

The urban growth boundaries in 2016 were virtually unchanged from 2007 , at 583 miles. A total of 335 preserved farm parcels shared 88.5 miles with the urban growth boundaries, so that 15.2 percent of the growth boundaries touched on a preserved farm parcel. These results suggest that preserving farmland along growth boundaries is a difficult strategy to implement, in part because the sale of a conservation easement is voluntary and the cost of preserving farmland near development is high. Moreover, landowners may perceive that the growth boundaries will move outward over time and that the sale of the farmland for development will occur eventually.

GIS can be used to compile the factors and the scores for the factors for farms under application for the sale of conservation easements. The scores include points for the proximity of an applicant farm to a farm that is already preserved. The scores are used to rank the order in which the applicant farms are appraised to determine the easement value, and generally the order in which applicant farms will be preserved. But GIS can also show the location of the applications that involve existing blocks of preserved farmland (Figure 3). If a main goal of the farmland preservation program is to create large blocks of preserved farmland, then applications for farms that would add to blocks of less than 250 acres or less than 500 acres may be preferred to farms that add to existing blocks of 500 or more acres.

\section{Study Limitations and Future Research}

This study concentrates on evaluating Lancaster County's acquisition of agricultural conservation easements to create large blocks of preserved farmland. The study does not incorporate (1) data on the amount of highly productive farmland that has been preserved; (2) direct sales of farm products from preserved farms to consumers; or (3) the change in the value of agricultural production in the county since the start of its farmland preservation program or, more specifically, the change in the value of production from preserved farms.

While preserving the farm from development is a first step, the second step is responsible management of the land to maintain and even enhance productivity over time. Soils are a priority in the Agricultural Preserve Board application ranking system. Soils data exist for each farm parcel in the county. This data could be keyed into a GIS database of preserved farms to measure the amount of prime farmland (NRCS Class I and II), soils of statewide importance (NRCS Class III), and any unique farmland (certain NRCS Class IV soils) that have been placed under conservation easements. ${ }^{3}$ About 54 percent of Lancaster County contains prime soils, and 18 percent contains soils of statewide importance (Daniels, 2000). Monitoring farms for compliance with soil and water conservation is essential for maintaining and increasing soil productivity and reducing agricultural runoff that pollutes waterways. Conservation district personnel who have the necessary soil conservation expertise have assisted the Preserve Board in monitoring farms and drafting conservation plans.

Lancaster County is one of the leading counties in the nation in direct sales to consumers, ranking seventh in 2005 (Lancaster County Board of Commissioners, 2005). A survey could be conducted to estimate the direct sales from preserved farms to consumers. Similarly, a survey could be conducted to estimate the increase in the value of production on preserved farms since they came under a conservation easement. From 1992 to 2012, the county's agricultural output more than doubled, from US $\$ 681$ million to US $\$ 1.475$ billion (in constant dollars) (USDA, 1992, 2014). Related

\footnotetext{
${ }^{3}$ Farms preserved by the Lancaster County Agricultural Preserve Board must have a Soil and Water Conservation Plan. The local Conservation District has also helped to monitor farms to ensure compliance.
} 
to the production of food is the access of new farmers and expanding farmers to land. One measure of this is the average age of farmers in a county. For the U.S., the average age was 58 years in 2012, and was 49 years in Lancaster County (USDA, National Agricultural Statistics Service [NASS], 2014). The younger the average age of farmers, the more likely it is that younger farmers have gained access to farmland.

Large agricultural landscapes exist at more than just the county level. Lancaster County is one of 10 counties in southeastern Pennsylvania and northern Maryland that have together preserved more than 600,000 acres (Daniels \& Wright, 2015). Further study of the growth management efforts in these counties that includes the use of GIS to analyze farmland preservation, how their agricultural economies are linked together, and changes in farm output and direct sales could provide further insights into the effectiveness or shortcomings of agricultural conservation easement programs. Such a study would build upon this paper and the study of agricultural conservation easements in the San Francisco Bay Area (Stoms et al., 2009).

Lancaster County has a mature farmland preservation program. A focus on growth management and preserving farmland in large blocks therefore is warranted, given that the county's population is projected to increase from 519,445 in 2012 to 652,000 in 2040 (Lancaster County Planning Commission, 2012). Farmland preservation cannot guarantee that a farm will be a successful business enterprise or even that the land will be actively farmed. But farmland preservation can keep the land from being converted to nonfarm uses and can maintain the potential for the land to be farmed in the future. An update of the GIS study in this paper should be undertaken every five to 10 years to track Lancaster County's progress in farmland preservation.

\section{A Final Note on Farmland Preservation Strengths and Weaknesses}

The fact that farmland preservation is voluntary on the part of the landowners is both a strength and weakness. The strength is that landowners willingly sell or donate a conservation easement on their property to restrict its use. Thus, there is no struggle over Fifth Amendment "takings" because landowners have voluntarily placed a conservation easement on their property for which they receive compensation in the form of cash and/or a tax deduction and even estate tax benefits. The voluntary aspect of farmland preservation is also a weakness, as it is not possible to compel the owner of a farm to sell or donate a conservation easement. For that reason, as Stoms et al. note, "planners can never be completely strategic" (2009, p. 1160). If the farmers next to a preserved farm do not want to sell or donate a conservation easement, then that preserved farm will continue to stand alone. Similarly, if farmers next to a block of preserved farmland do not want to preserve their farms, then the block will not increase. And finally, farmland owners along a growth boundary may prefer to wait for the boundary to expand around them, and then sell their farms for development. Nevertheless, farmland preservation programs succeed when large numbers of farmland owners within a local area voluntarily sell or donate a conservation easement.

\section{Conclusions}

Preserving large agricultural landscapes is fundamental for long-term success in maintaining a critical mass of farms and farmland. This involves the preservation not only of large farms but also of smaller, intensively cultivated farms, as has occurred in Lancaster County. Gauging progress over time is essential for identifying whether farmland preservation efforts are creating large contiguous blocks or scattered pockets of preserved farmland. Such analysis can help farmland preservationists to focus strategically on preserving farmland next to or close to existing preserved farm parcels.

A comparison of two time periods indicates good progress in Lancaster County toward creating preserved blocks of 1,000 or more acres. The number of preserved parcels and acres in this category doubled between 2007 and 2016. However, the number of acres in blocks of less than 250 acres, although lower in 2016, remains a concern.

Stoms et al. (2009) note the need for new tools that planners and land preservation programs can use to identify where to acquire conservation easements as strategically as possible. GIS analysis can 
provide new ways to determine the effectiveness of farmland preservation efforts. With adequate digitized data for agricultural zoning, growth boundaries, and preserved farm parcels, the analysis can inform local governments and land trusts about where their efforts are succeeding and where to focus future efforts. Two measures computed in this study - consistency between farmland preservation and agricultural zoning, and the degree of contiguity of preserved farmland - can easily be transferred to evaluate the performance of other public (township, county, or state) and private land trust farmland preservation programs.

The experience of Lancaster County shows that it is possible to preserve a significant amount of farmland along growth boundaries and in effect make parts of the boundaries permanent. Preserving farmland along growth boundaries will compel future growth boundary expansions to occur away from some high-quality agricultural areas. But this strategy has enjoyed somewhat less success than the preservation of farmland in agricultural zones and in large contiguous blocks.

The Lancaster County experience demonstrates that three techniques-effective agricultural zoning, growth boundaries, and the acquisition of conservation easements-can work together in a farmland preservation package of approaches. Agricultural zoning discourages most nonfarm development and holds down the cost of purchasing conservation easements; growth boundaries limit the extension of sewer and water lines and urban development into the countryside; and the purchase of conservation easements on tens of thousands of acres gives greater certainty for continued farming over time.

\section{Acknowledgements}

Thank you to the following, each of whom provided data on Lancaster County's farmland preservation policies and results: Matt Knepper, Director, Lancaster County Agricultural Preserve Board; June Mengel, Farmland Preservation Specialist, Lancaster County Agricultural Preserve Board; Dean Seversen, Lancaster County Planning Commission.

\section{References}

American Farmland Trust. (2012). Status of local PACE programs. Washington, D.C.: American Farmland Trust, Farmland Information Center. Retrieved from http://www.farmlandinfo.org/sites/default/ files/Local\%20PACE_09-2012.pdf

American Farmland Trust. (2013, February 6). Surveys reveal that 5 million acres of U.S. agricultural land are permanently protected by governments and land trusts [Press release]. Washington, D.C.: American Farmland Trust, Farmland Information Center. Retrieved from http://www.farmlandinfo.org/surveys-reveal5-million-acres-us-agricultural-land-arepermanently-protected-governments-and-land

American Farmland Trust. (2016a). Farmland. Washington, D.C.: American Farmland Trust. Retrieved from https://www.farmland.org/ourwork/areas-of-focus/farmland

American Farmland Trust. (2016b). Status of state PACE programs. Washington, D.C.: American Farmland Trust, Farmland Information Center. http://www.farmlandinfo.org/sites/default/files/ State Purchase of Agricultural Conservation Eas ement Programs 2016 AFT FIC 09-16.pdf

Bengston, D. N., Fletcher, J. O., \& Nelson, K. C. (2004). Public policies for managing urban growth and protecting open space: Policy instruments and lessons learned in the United States. Landscape and Urban Planning, 69(2-3), 271-286. http://dx.doi. org/10.1016/j.landurbplan.2003.08.007

Brabec, E., \& Smith, C. (2002). Agricultural land fragmentation: The spatial effects of three land protection strategies in the eastern United States. Landscape and Urban Planning, 58(2-4), 255-268. http://dx.doi.org/10.1016/S0169-2046(01)00225-0

Daniels, T. (1991). The purchase of development rights: Preserving agricultural land and open space. Journal of the American Planning Association, 57(4), 421-431. http://dx.doi.org/10.1080/089419200279090

Daniels, T. (2000). Integrated working landscape protection: The case of Lancaster County, Pennsylvania. Society \& Natural Resources, 13(3), 261271. http://dx.doi.org/10.1080/089419200279090

Daniels, T. (2010). The use of green belts to control sprawl in the United States. Journal of Planning Practice and Research, 25(2), 255-271. http://dx.doi.org/10.1080/02697451003740288 
Daniels, T., \& Bowers, D. (1997). Holding our ground: Protecting America's farms and farmland. Washington, D.C.: Island Press.

Daniels, T., \& Wright, J. (2015). Preserving large landscapes. Planning, 81(10), 33-39.

Gerber, J.-D., \& Rissman, A. R. (2012). Land conservation strategies: The dynamic relationship between acquisition and land use planning. Environment and Planning A, 44(8), 1836-1855. http://dx.doi.org/10.1068/a44395

Heimlich, R., \& Anderson, W. D. (2001). Development at the urban fringe and beyond: Impacts on agriculture and rural land (AER Report 803). U.S. Department of Agriculture, Economic Research Service. Washington, D.C.: Government Printing Office. https://www.ers.usda.gov/publications/pubdetails/?pubid $=41364$

Hoobler, B. M., Vance, G. F., Hamerlinck, J. D., Munn, L. C., \& Hayward, J. A. (2003). Applications of land evaluation and site assessment (LESA) and a geographic information system (GIS) in East Park County, Wyoming. Journal of Soil and Water Conservation, 58(2), 105-112. http://www.jswcon line.org/content/58/2/105.short

Lancaster County Agricultural Preserve Board. (2010). Agricultural conservation easement program guidelines. Lancaster, Pennsylvania: Lancaster County Agricultural Preserve Board. http://web.co.lancaster.pa.us/DocumentCenter/ Home/View/142

Lancaster County Government Center. (n.d.). Agricultural Preserve Board. Retrieved May 21, 2017, from http://web.co.lancaster.pa.us/126/ Agricultural-Preserve-Board

Lancaster County Board of Commissioners. (2005). Blue ribbon commission for agriculture in Lancaster County report. Lancaster, Pennsylvania: Lancaster County Board of Commissioners. http://web.co.lancaster.pa.us/DocumentCenter/ Home/View/140

Lancaster County Planning Commission. (2010). Agricultural zoning district guidelines for Lancaster County, Pennsylvania. Lancaster, Pennsylvania: Lancaster County Planning Commission. http://www.lancastercountyplanning.org/ DocumentCenter/Home/View/107

Lancaster County Planning Commission. (2012). 2040 Population Projections for Lancaster County and
Municipalities. Lancaster, Pennsylvania: Lancaster County Planning Commission. http://www.lancas tercountyplanning.org/DocumentCenter/View/60

Lancaster Farmland Trust. (2016). 2015 highlights. Retrieved from http://www.lancasterfarmlandtrust. org/LGT\%20HighLite\%202015_FINAL.pdf

Land Trust Alliance. (2015). 2015 National Land Trust Census. Washington, D.C.: Land Trust Alliance. https://www.landtrustalliance.org/about/nationalland-trust-census

Liu, X., \& Lynch, L. (2011). Do agricultural land preservation programs reduce farmland loss? Evidence from a propensity score matching estimator. Land Economics, 87(2), 188-201. http://dx.doi.org/10.3368/le.87.2.183

Lynch, L., \& Liu, X. (2007). Impact of designated preservation areas on rate of preservation and conversion: Preliminary evidence. American Journal of Agricultural Economics, 89(5), 1205-1210. http://dx.doi.org/10.1111/j.14678276.2007.01085.x

Lynch, L., \& Musser, W. (2001). A relative efficiency analysis of farmland preservation programs. Land Economics, 77(4), 577-594. http://dx.doi.org/10.2307/3146942

Machado, E. A., Stoms, D. M., Davis, F. W., \& Kreitler, J. (2006). Prioritizing farmland preservation costeffectively for multiple objectives. Journal of Soil and Water Conservation, 61(5), 250-258.

Natural Resources Conservation Service. (2017). Agricultural conservation easement program. Washington, DC: Natural Resources Conservation Service. https://www.nrcs.usda.gov/wps/portal/nrcs/main /national/programs/easements/acep/

Schilling, B. D., Esseks, J. D., Duke, J. M., Gottlieb, P. D., \& Lynch, L. (2015). The future of preserved farmland: Ownership succession in three MidAtlantic states. Journal of Agriculture, Food Systems, and Community Development, 5(2), 129-153. http://dx.doi.org/10.5304/jafscd.2015.052.008

Sokolow, A. D. (2006a). A national view of agricultural easement programs: Easements and local planning (Report 3). DeKalb, Illinois \& Davis, California: American Farmland Trust, Agricultural Issues Center, and University of California, Davis. http://toolkit.valley blueprint.org/sites/default/files/02 national-agprograms farmland-trust 2006 0.pdf 
Sokolow, A. D. (2006b). A national view of agricultural easement programs: Measuring success in protecting farmland (Report 4). DeKalb, Illinois \& Davis, California: American Farmland Trust, Agricultural Issues Center, University of California, Davis. http://www.communitiescommittee.org/pdfs/AF T\%20agricultural $\% 20$ easement $\% 20$ report.pdf

Sokolow, A. D., \& Zurbrugg, A. (2003). A national view of agricultural easement programs: Profiles and maps (Report

1). DeKalb, Illinois \& Davis, California: American Farmland Trust, Agricultural Issues Center, University of California, Davis.

http://www.farmlandinfo.org/national-assessmentagricultural-easement-programs

Sorensen, A., Greene, R., Russ, K. (1997). Farming on the edge. DeKalb, Illinois: American Farmland Trust, Center for Agriculture in the Environment. https://www.farmland.org/farming-on-the-edge Stoms, D. M, Jantz, P., Davis, F. W., \& DeAngelo, G. 2009. Strategic targeting of agricultural conservation easements as a growth management tool. Land Use Policy, 26(4), 1149-1161. http://dx.doi.org/10. 1016/j.landusepol.2009.02.004

Tulloch, D. L., Myers, J. R., Hasse, J. E., Parks, P. J., \& Lathrop, R. G. (2003). Integrating GIS into farmland preservation policy and decision making. Landscape and Urban Planning, 63(1), 33-48. http://dx.doi.org/10.1016/S0169-2046(02)00181-0

U. S. Bureau of the Census. (2011). American Fact Finder, Community Facts. Washington, D.C.: Bureau of the Census. https:// factfinder.census.gov/

U. S. Department of Agriculture. (1992). Census of Agriculture, 1992. Vol. 1, Ch. 2: County Level. Pennsylvania: County Summary Highlights, 1992. Washington, D.C.: USDA Census of Agriculture Historical Archive. https://www.agcensus.usda. gov/Publications/2012/

U. S. Department of Agriculture, National Agricultural Statistics Service. (2014). Census of Agriculture, 2012: County Profile: Lancaster County, Pennsylvania. Washington, D.C.: USDA Census of Agriculture. https://www.agcensus.usda.gov/Publications/2012

U. S. Department of Agriculture. (2015). Summary report: 2012 national resources inventory. Washington, D.C. \& Ames, Iowa: Natural Resources Conservation Service, Center for Survey Statistics and Methodology, and Iowa State University. https://www.nrcs.usda.gov/Internet/FSE DOCU MENTS/nrcseprd396218.pdf 